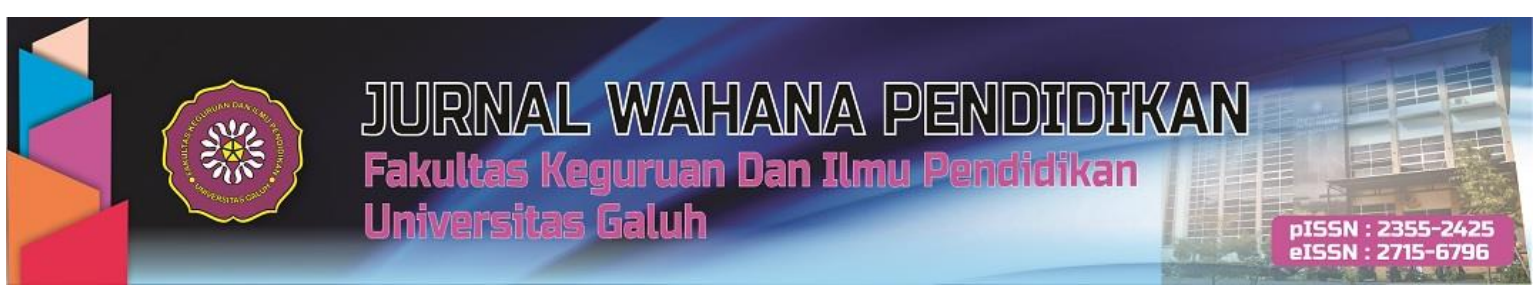

https://jurnal.unigal.ac.id/index.php/jwp

\title{
PEMBELAJARAN BERBASIS STEM UNTUK MENINGKATKAN PEMAHAMAN KONSEP ENERGI DAN KETERAMPILAN BERPIKIR KREATIF MELALUI PROJEK PLTMH
}

\author{
Ai Deti Heryanti \\ SMP Negeri 4 Sumedang, Jl. Pangeran Suriaatmaja No. 12 Sumedang, Kab. Sumedang, Indonesia \\ Email: aidetiheryanti@gmail.com
}

\begin{abstract}
The students' reasoning ability is still very low. One of the reasons is due to the lack of opportunities for students to develop optimally their ability to think creatively in the learning process. Research in the form of Classroom Action Research (CAR) conducted in 2 cycles. The results showed that in the first cycle with an N-gain value of 0.54 was in the medium category. It increased in cycle II with an $\mathrm{N}$-gain value of 0.72 which was in the high category. The average value of creative thinking skills in cycle I and cycle 2 expressed by the average creative assessment process which has increased with the acquisition in cycle 1 of 62.4 which is categorized sufficiently and in cycle 2 of 78 which is categorized well. The average creative assessment of products in cycle 1 of 63.2 was categorized sufficiently and had an increase in cycle 2 with an average rating of 80.3 in the good category. The results of the analysis proved that STEM-based learning through PLTMH projects was able to help students in class VII D students of SMPN 4 Sumedang, Indonesia to improve the concept of energy and their creative thinking skills.
\end{abstract}

Keywords: STEM, Energy concepts, creative skills.

\section{ABSTRAK}

Kemampuan bernalar peserta didik masih sangat kurang. Salah satu penyebabnya dikarenakan kurangnya kesempatan peserta didik untuk mengembangkan secara optimal kemampuan berpikir dan kreativitasnya dalam proses pembelajaran. Penelitian berbentuk Penelitian Tindakan Kelas (PTK) sebanyak 2 siklus. Hasil pemahaman konsep siswa pada konsep Energi pada siklus I dengan nilai N-gain sebesar 0,54 kategori sedang. Sedangkan pada siklus II meningkat dengan nilai $\mathrm{N}$-gain sebesar 0,72 kategori tinggi. Terjadi peningkatan pemahaman konsep Energi pada media PLTMH melalui pendekatan STEM dengan nilai Gain pada siklus 1 sebesar 0,54 kategori sedang menjadi 0,72 pada siklus 2 dengan kategori tinggi. Nilai rata-rata ketrampilan berfikir kreatif siklus I dan siklus 2 yang dinyatakan dengan rata-rata penilaian kreatif proses mengalami peningkatan dengan perolehan pada siklus 1 sebesar 62,4 yang dikategorikan cukup dan pada siklus 2 sebesar 78 yang dikategorikan baik. Rata-rata penilaian kreatif produk pada siklus 1 sebesar 63,2 dikategorikan cukup dan mengalami peningkatan di siklus 2 dengan rata rata penilaian sebesar 80,3 dengan kategori baik. Hasil analisis membuktikan bahwa pembelajaran berbasis STEM melalui projek PLTMH, mampu membantu siswa dalam meningkatkan penguasaan konsep Energi dan ketrampilan berfikir kreatif pada siswa kelas VII D SMPN 4 Sumedang.

Kata Kunci: STEM, konsep Energi, keterampilan kreatif.

Cara sitasi:

Heryanti, Ai Deti. (2020). Pembelajaran Berbasis STEM Untuk Meningkatkan Pemahaman Konsep Energi Dan Keterampilan Berpikir Kreatif Melalui Projek PLTMH. Jurnal Wahana Pendidikan, 7 (1), 77-84.

Sejarah Artikel:

dikirim desember 2019, direvisi januari 2020, diterima januari 2020 


\section{PENDAHULUAN}

Kurikulum 2013 diterjemahkan dalam praktik pendidikan dengan tujuan agar peserta didik memiliki kompetensi yang diperlukan bagi kehidupan masyarakat di masa kini dan di masa mendatang. Tuntutan Kurikulum 2013 pada mata pelajaran IPA yaitu mengembangkan kemampuan berpikir ilmiah untuk menyelesaikan masalah yang berkaitan dengan peristiwa alam sekitar. Kurikulum 2013 menghendaki peserta didik berpikir HOTS (Higher Order Thinking Skill). Guru tidak lagi memberitahu peserta didik, melainkan peserta didik harus mencari tahu. Mencari tahu artinya butuh proses berpikir cerdas dan kreatif. Berpikir cerdas dan kreatif berarti berpikir tingkat tinggi. Kemampuan berpikir tingkat tinggi yang diperkenalkan sejak dini dibangku sekolah akan berdampak positif kelak kemudian hari.

Melihat kenyataan saat ini, banyak peserta didik belum memiliki kemampuan berpikir tingkat tingi, masih pada kemampuan menghafal. Peserta didik belum mampu menyelesaikan suatu masalah apabila peserta didik tersebut menelaah suatu permasalahan sehingga mampu menggunakan pengetahuannya ke dalam situasi baru. Untuk itu peserta didik harus dilatih untuk bisa bernalar, agar dapat memecahkan masalah dalam kehidupan sehari-hari, sampai bisa menciptakan (membuat) produk yang dapat menjadi solusi memecahkan masalah.

Hasil studi pendahuluan yang dilakukan kepada siswa kelas VII D di SMP Negeri 4 Sumedang, hanya satu kelompok (12,5\%) yang dapat memberikan pertanyaan yang mengarah pada penyelidikan ilmiah. Kemampuan bernalar peserta didik masih sangat kurang. Hal tersebut terlihat pada keseharian peserta didik belum bisa memberikan pertanyaan yang sifatnya bernalar dalam penyelidikan ilmiah untuk memecahkan masalah.

Salah satu penyebabnya dikarenakan kurangnya kesempatan peserta didik untuk mengembangkan secara optimal kemampuan berpikir dan kreativitasnya dalam proses pembelajaran. Untuk menjawab dan membekali peserta didik dengan kompetensi-kompetensi yang dituntut di atas, ada beberapa model pembelajaran yang layak untuk diaplikasikan dalam pembelajaran abad 21 , misalnya model pembelajaran Project Based Learning (PJBL), Inquiry Based Learning (IBL), dan STEM Project Based Learning.

Pendekatan STEM (Science, Technology, Engineering, and Mathematics) menjadi alternatif solusi digunakan dalam pembelajaran. STEM merupakan sebuah pendekatan pembelajaran yang menggunakan pendekatan antar ilmu dimana pengaplikasiannya dilakukan dengan pembelajaran aktif berbasis masalah. Melalui pendekatan pembelajaran STEM, Asmuniv (2015) mengatakan bahwa peserta didik mendapatkan manfaat atas konsep yang sudah dipahami dengan adanya produk rekayasa, aplikasi dari konsep yang sudah dipelajari. SDM yang menguasai STEM antara lain diproyeksikan akan menduduki posisi yang lebih baik di berbagai pekerjaan, dapat menjawab tantangan teknologi, peningkatan kemahiran dan pemahaman saintifik, dan menjadi kunci dalam kemajuan dan inovasi.

Penelitian sebelumnya, Pradita (2015) menyebutkan bahwa pembelajaran melalui PJBL mampu meningkatkan kemampuan berpikir kritis pada pembelajaran Fisika. Pada penelitian ini, peneliti bermaksud untuk melibatkan peserta didik agar dapat bernalar untuk bisa memecahkan masalah dengan mengembangkan kreatifitasnya sampai menghasilkan produk dari konsep yang sudah dipelajari. Hasanah, Lt. (2019) menyebutkan bahwa guru belum menggunakan metode yang tepat, sehingga proses pembelajaran kurang efektif dan efisien, serta pengaruh karakteristik siswa. Munandar (1999) mengatakan bahwa untuk menjadi kreatif seseorang harus melakukan sesuatu karena dorongan internal. Melalui pendekatan pembelajaran STEM, konsep Energi dengan projek PLTMH yang Unit pembelajarannya dikembangkan oleh P4TK IPA. Penelitian ini berjudul: Pembelajaran Berbasis STEM untuk Meningkatkan Pemahaman Konsep Energi dan Keterampilan Berpikir Kreatif melalui Projek PLTMH.

\section{METODE PENELITIAN}

Dalam penelitian ini, yang dijadikan subyek penelitian adalah siswa kelas VII D Tahun ajaran 2018/2019 yang berjumlah 37 siswa. Teknik pemilihan sampel pada penelitian ini adalah cluster random sampling. Penelitian yang digunakan adalah penelitian tindakan kelas (PTK) yang terdiri dari 2 siklus. 
Prosedur dalam penelitian siklus I antara lain: 1. Perencanaan Peneliti menyusun perangkat pembelajaran antara lain RPP, Silabus, LKS dan soal pretes postes ketrampilan berfikir kreatif. 2. Pelaksanaan Tindakan Siklus 1 dilaksanakan pada tanggal 28 dan 29 Agustus 2018 dengan proses pelaksanaan pembelajaran menggunakan model pembelajaran PJBL berbasis STEM yang terdir atas 5 tahap yaitu a) Orientasi: guru menjelaskan mengenai pembangkit listrik tenaga air. kemudian siswa dibimbing untuk membuat PLTMH dari bahan bekas yang bertujuan agar memancing kreativitas siswa dalam membuat suatu teknologi sederhana. b) merumuskan masalah: siswa merumuskan masalah berdasarkan fenomena yang diamati yaitu materi yang diberikan dan alat bahan yang disediakan. c) Merumuskan hipotesis: siswa saling curah pendapat dalam membentuk hipotesis terhadap rumusan masalah yang telah dibuat. d) Mengumpulkan data: dengan melakukan praktikum secara berkelompok. e) Menyimpulkan hipotesis: menyimpulkan hasil praktikum. 3. Pengamatan Pada tahap pengamatan meliputi hasil pengamatan pelaksanaan pembelajaran dan data hasil pretes dan postes ketrampilan berfikir kreatif. Pada penelitian ini sebelum implementasi model pembelajaran dilakukan tes awal (pretes) dan setelah implementasi model pembelajaran dilakukan tes akhir (postes). 4. Refleksi Pada kegiatan refleksi dikaji kekurangan-kekurangan yang muncul pada siklus 1 . Ternyata pada siklus 1 belum mencapai target sehingga perlu dilakukan siklus 2 yang dilaksanakan pada tanggal 5 dan 6 September 2018 yang terdiri atas 5 tahap yaitu a) Penerapan model pembelajaran PjBL pada pertemuan pertama dilakukan 3 sintak pembelajaran yaitu: memulai dengan pertanyaan mendasar dan menentukan proyek, menyusun perencanaan proyek, dan menyusun jadwal proyek. Terdapat dua tujuan yang ingin dicapai pada pertemuan pertama.

Tujuan yang pertama, peneliti ingin melihat kreativitas peserta didik dalam membuat perencanaan produk dengan bantuan media internet dan wawasan secara luas. Tujuan kedua, peneliti ingin melihat kreativitas peserta didik saat memecahkan masalah dalam merencanakan produk inovasi. Pelaksanaan yang dilakukan untuk mencapai tujuan pertama, peserta didik melakukan tahapan penentuan proyek, menyusun perencanaan proyek, dan menyusun jadwal proyek.

Adapun sintak pada pertemuan kedua yaitu pelaksanaan proyek, memantau peserta didik dan kemajuan proyek. Keterlaksanaan proses pembelajaran pada pertemuan kedua berjalan dengan baik.

Tujuan pada pertemuan kedua yaitu melihat kreativitas peserta didik dalam pengaplikasian perencanaan produk PLTMH. yang telah dirancang pada pertemuan pertama. Kegiatan pelaksanaan proyek yang dilaksanakan yaitu, pembuatan produk sesuai dengan perencanaan.

Sintak akhir yang diterapkan pada model pembelajaran PjBL dilaksanakan pada pertemuan 3. Adapun sintak pertemuan tiga yaitu penilaian terhadap hasil proyek dan evaluasi. Tujuan yang ingin dicapai pada pertemuan tiga yaitu menganalisis hasil produk yang telah dihasilkan dan melakukan pengembangan produk yang telah dibuat pada pertemuan dua. Jika belum berhasil atau kurang optimal, peserta didik menentukan ulang proyek, merencanakan, dan menyusun jadwal proyek. Hal tersebut untuk melihat tingkat kreativitas peserta didik.

Instrumen penelitian pemahaman konsep Energi dan keterampilan berfikir kreatif yang meliputi RPP, Silabus, LKS dan soal tes. Hasil pretes dan postes diolah dan dianalisis untuk mengetahui peningkatan kemampuan pemecahan masalah siswa. Untuk mengetahui peningkatan hasil belajar antara sebelum dan sesudah pembelajaran dari setiap siklus diklasifikasikan berdasarkan penilaian nilai presentase gain ternormalisasi yang dihitung dengan rumus dari Larkin, J. H., dan Reif, F. (dalam Swistoro Eko, 2012):

$$
\mathrm{N} \text {-gain }=\frac{(S \text { post })-(\text { S pre })}{(S \text { max }-S \text { pre })}
$$

Dimana g adalah gain yang dinormalisasi, Smax adalah skor maksimum (ideal) dari tes awal dan tes akhir, Spost adalah skor tes akhir, sedangkan Spre adalah skor tes awal. Tinggi rendahnya skor gain yang dinormalisasi ( $\mathrm{N}$-gain) dapat diklasifikasikan dalam tiga kategori, yaitu:

$\mathrm{N}$-gain $>0,7$ kategori tinggi, $\quad 0,3 \leq \mathrm{N}$-gain $\leq 0,7$ kategori sedang,

$\mathrm{N}$-gain $<0,3$ berkategori rendah. 
Sumber data berasal dari guru dan siswa yang diperoleh melalui observasi, wawancara, tes dan kajian dokumen. Lembar observasi peserta didik dengan menggunakan rubrik penilaian kritis -kreativitas (Proses dan produk), yang sudah dikembangkan oleh P4TK IPA, yang mengacu ada struktur intelek Guilford yang telah distandarisasi. Rubrik penilaian digunakan untuk mengetahui pembelajaran dengan menggunakan pendekatan Stem dengan projek PLTMH terhadap keterampilan berpikir kritis.

\section{HASIL DAN PEMBAHASAN}

\section{Analisis Kemampuan Berpikir Kreatif}

Lembar kerja siswa pada proyek PLTMH (Pembangkit Listrik Tenaga Mikro Hidro) selama pembelajaran baik pada siklus 1 maupun siklus 2 digunakan untuk mengukur kemampuan berpikir kreatif siswa pada proses pembelajaran dan penilaian produk. Jawaban siswa dianalisis kemampuan berpikir kreatifnya meliputi 4 indikator yaitu memulai proyek, membangun pengetahuan, pemahaman, dan keterampilan, mengembangkan dan merevisi gagasan dan produk, menyajikan produk dan jawaban atas pertanyaan yang mendorong (driving question). Berdasarkan rubrik instrument penilaian berpikir kreatif yang dikembangkan oleh P4TK IPA didapat hasil sebagai berikut:

Tabel 1

Rubrik Penilaian Kritis Dan Kreatif (Proses)

\begin{tabular}{clcc}
\hline \multirow{2}{*}{ NO Kreativitas \& Peluang Inovasi di Tahapan Proyek } & \multicolumn{2}{c}{$\begin{array}{c}\text { Skor rata rata peserta } \\
\text { didik dalam \% }\end{array}$} \\
\cline { 3 - 4 } & \multicolumn{2}{c}{ Siklus 1 } & Siklus 2 \\
\hline 1 & $\begin{array}{l}\text { Memulai Proyek: } \\
\text { Menentukan tantangan kreatif }\end{array}$ & 58,6 & 76,5 \\
2 & $\begin{array}{l}\text { Membangun pengetahuan, pemahaman, dan keterampilan: } \\
\text { identifikasi Sumber informasi }\end{array}$ & 72,0 & 75,2 \\
3 & $\begin{array}{l}\text { Mengembangkan dan Merevisi Gagasan dan Produk: } \\
\text { menghasilkan dan memilih gagasan }\end{array}$ & 70,6 & 79,3 \\
4 & $\begin{array}{l}\text { Menyajikan Produk dan jawaban atas Pertanyaan yang mendorong (driving } \\
\text { question): } \\
\text { Menyajikan hasil pekerjaan kepada Pengguna / target audiens }\end{array}$ & 78,4 & 81 \\
\hline & Rata rata penilaian kreatif proses & 62,4 & 78 \\
\hline
\end{tabular}

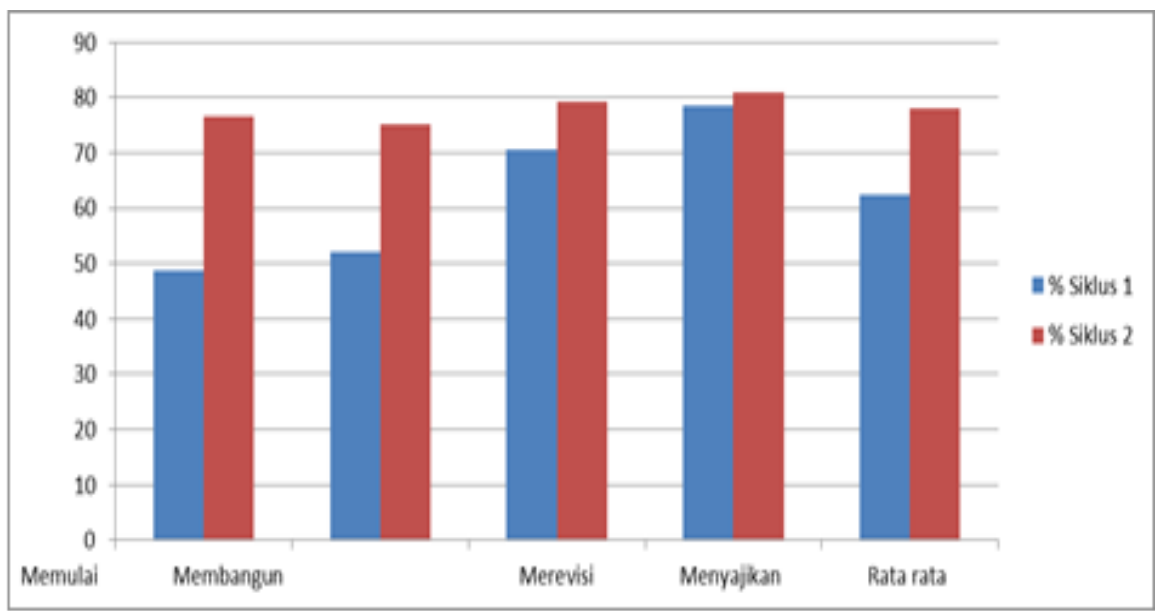

Gambar 1. Grafik Penilaian Kritis Dan Kreatif (Proses)

Tabel 2

Rubrik Penilaian Kreativitas Dan Inovasi (Produk)

\begin{tabular}{|c|c|c|}
\hline \multirow{2}{*}{ No. } & \multirow{2}{*}{$\begin{array}{c}\text { Kreativitas \& Peluang Inovasi di Tahapan } \\
\text { Proyek }\end{array}$} & Skor rata rata peserta didik dalam \% \\
\hline & & Siklus 1 \\
\hline
\end{tabular}




\begin{tabular}{llll}
2 & Nilai & 64,4 & 80,6 \\
3 & Gaya & 70,6 & 83,8 \\
\hline & Rata rata penilaian kreatif produk & 63,2 & 80,3 \\
\hline
\end{tabular}

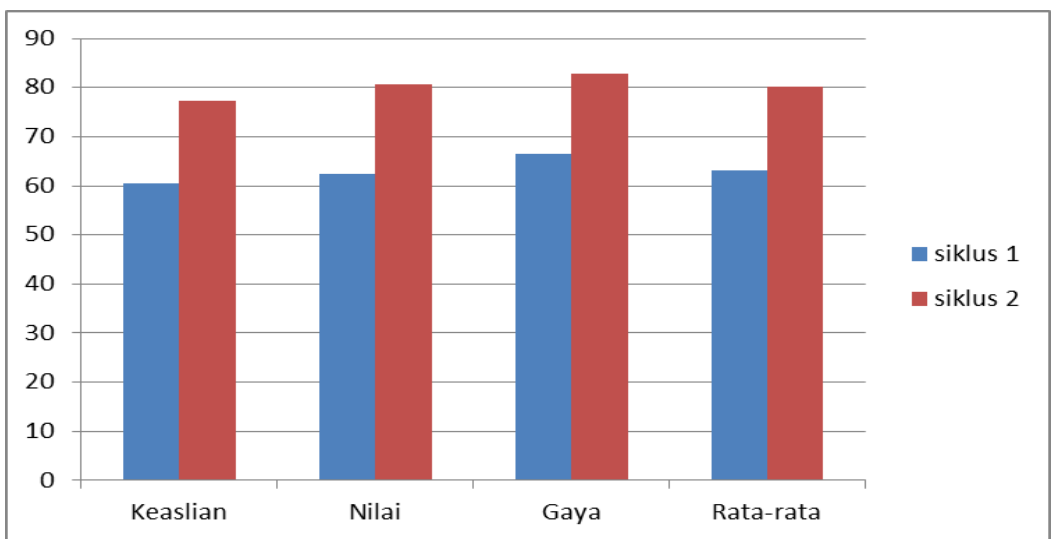

PENSKORAN:

Gambar 2. Grafik Penilaian Kreativitas Dan Inovasi (Produk)

\section{Penilaian keterampilan}

$$
K_{i}=\frac{\text { Jumlah }_{\text {total }}}{\text { Jumlah }_{\text {max }}} * 100 \%
$$

Keterangan:

$\mathrm{K}_{\mathrm{i}}=$ Kinerja Stem

Tabel 3

Rentang kemampuan peserta didik mengikuti pembelajaran Stem

\begin{tabular}{ccl}
\hline Kemampuan & Rentang Nilai & \multicolumn{1}{c}{ Interpretasi } \\
\hline Amat Baik & $91-100$ & siswa dapat mengikuti pembelajaran Stem dengan amat baik \\
Baik & $76-90$ & siswa dapat mengikuti pembelajaran Stem dengan baik \\
Cukup & $61-75$ & siswa dapat mengikuti pembelajaran Stem dengan cukup baik \\
Sedang & $51-60$ & siswa kurang dapat mengikuti pembelajaran Stem \\
Kurang & $\leq 50$ & siswa tidak dapat mengikuti pembelajaran Stem \\
\hline
\end{tabular}

Berdasarkan Rentang kemampuan peserta didik mengikuti pembelajaran Stem, dalam setiap aspek baik pada penilaian kreatifitas, diperoleh nilai dalam rentang 76-90, dengan predikat kemampuan Baik. Dengan demikian, dapat diinterpretasikan bahwa peserta didik kelas VII D di SMPN 4 Sumedang, dapat mengikuti pembelajaran STEM dengan baik.

Peningkatan pemahaman atau penguasaan konsep peserta didik setelah pembelajaran Energi dengan pendekatan STEM dilakukan. Data yang didapat dianalisis terdapat peningkatan hasil belajar dengan membandingkan nilai post-test dan pretest. Berikut adalah hasil nilai rata-rata peningkatan hasil belajar dengan menggunakan diagram batang:

Tabel 4

Data Hasil Pemahaman konsep energi pada siklus 1 dan siklus 2

\begin{tabular}{lcc}
\hline \multicolumn{1}{c}{ Penilaian } & siklus 1 & Siklus 2 \\
\hline Rata-rata Pretest & 45.2 & 45.2 \\
Rata-rata Postes & 74.8 & 84.6 \\
Nilai Gain & 0.54 & 0.72 \\
Gain (Prosentase) & 54 & 72 \\
\hline
\end{tabular}




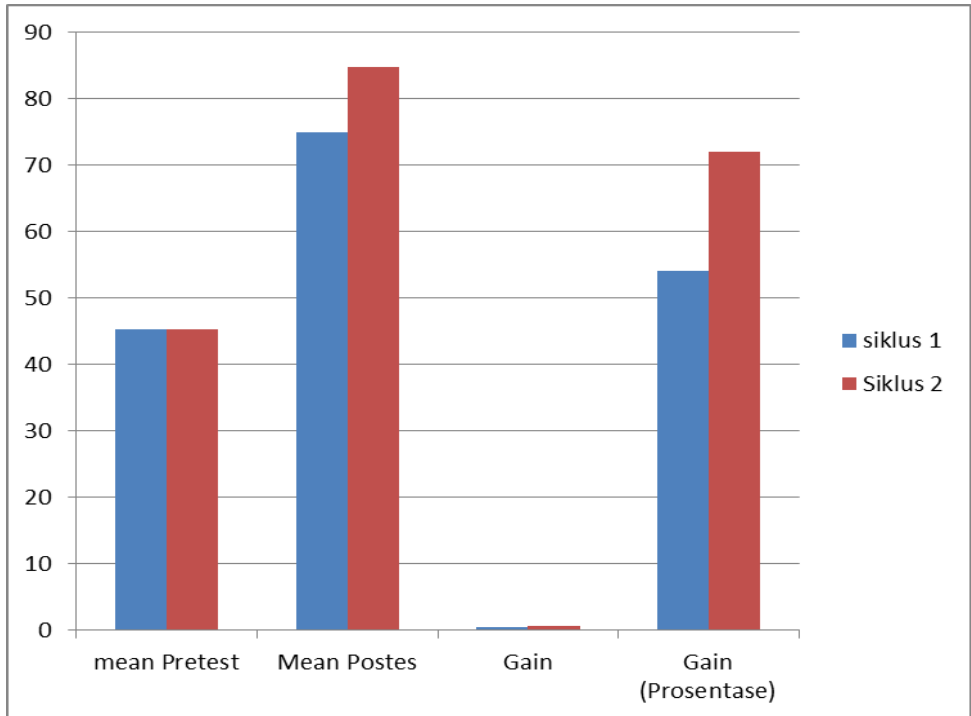

Gambar 3. Grafik Pemahaman konsep energi pada siklus 1 dan siklus 2

Tabel 5. Rekapitulasi Hasil Test Pemahaman Konsep Energi

\begin{tabular}{|c|c|c|c|c|}
\hline $\bar{\infty}$ & Jumlah peserta test & 37 orang & JUMLAH & 1770 \\
\hline$\supseteqq$ & Jumlah yang lulus & 36 orang & TERKECIL & 60.00 \\
\hline $\bar{E}$ & Jumlah yang tidak lulus & 1 orang & TERBESAR & 100.00 \\
\hline 岁 & Jumlah di atas rata-rata & 12 orang & RATA-RATA : & 80.45 \\
\hline$\overline{\widetilde{w}}$ & Jumlah di bawah rata- rata & 25 orang & SIMPANGAN BAKU : & 9.50 \\
\hline
\end{tabular}

\section{PEMBAHASAN}

Dari hasil penelitian yang dilakukan didapatkan hasil tes ketrampilan berfikir kreatif siswa pada siklus 1 masih belum memenuhi target yaitu sebesar 80 . Baru ada 4 dari 8 kelompok yang berhasil membuat produk PLTMH dengan indicator keberhasilan lampu dapat menyala. Namun dari 4 kelompok yang sudah berhasil membuat produk PLTMH, belum bisa melakukan pengukuran kuat arus listik dari indicator nyala lampu dan pembuatan grafik. Solusi dilakukan kegiatan pengukuran arus dan pembuatan grafik dan dilanjutkan melalui pembelajaran siklus kedua. Selain itu masih banyak anak yang nilainya belum mencapai ketuntasan, hal ini dikarenakan pembelajaran yang kurang maksimal dan diskusi dalam setiap kelompok belum berjalan lancar karena kurangnya kerja sama dan masih ada peserta didik yang membuat keributan sendiri sehingga mereka kurang memahami materi yang dipelajari sehingga masih perlu di lakukan penelitian siklus 2. Setelah dilakukan perlakuan siklus 2 dihasilkan tes ketrampilan berfikir kreatif siswa dan tes pemahaman konsep siswa sudah mencapai terget yaitu sebesar 80 sehingga penelitian cukup sampai siklus 2 .

Pada tabel 1 kita dapat melihat bahwa nilai perolehan skor dari setiap indikator ketrampilan berpikir kreatif siswa berbeda-beda. Pada siklus 1 Indikator berpikir kreatif yang paling tinggi adalah menyajikan produk dengan nilai sebesar 78,4 dan indikator berpikir kreatif yang paling rendah adalah menentukan tantangan kreatif dengan nilai sebesar 48,6, begitupula pada siklus 2 Indikator berpikir kreatif yang paling tinggi adalah juga pada keterampilan menyajikan produk dengan nilai sebesar 81 dan indikator berpikir kreatif yang paling rendah adalah menentukan tantangan kreatif dengan nilai sebesar 76,5 . Hal ini dikarenakan pada keterampilan berpikir memulai proyek untuk menentukan tantangan kreatif terkait peristiwa dalam kehidupan sehari-hari dan dapat diperoleh dari pengalaman kehidupan sehari-hari mereka dalam lingkungan sekitar, sehingga peneliti dapat 
menyimpulkan bahwa siswa tersebut memiliki pengetahuan yang luas sehingga mampu memberikan gagasan dengan kreatif.

Sedangkan nilai terendah kedua pada indikator keterampilan berpikir membangun pengetahuan, pemahaman dan keterampilan. Siswa dituntut untuk memberikan jawaban yang tidak lazim, yang lain dari yang lain, yang jarang diberikan kebanyakan orang sedangkan mayoritas siswa menjawab dengan jawaban yang sama. Menurut Piaget pada penelitian Fatimah Ibda yang berjudul "Perkembangan Kognitif: Teori Jean Piaget" perkembangan intelektual siswa SMP berada pada tahap operasional konkrit dan operasional formal sehingga pemikiran abstrak mereka masih belum dengan baik. Model inkuiri dapat meningkatkan pemahaman konsep mahasiswa, serta meningkatkan aktivitas belajar mahasiswa. Oleh karena itu, pembelajaran berbasis inkuiri dengan supplement modul mampu meningkatkan hasil belajar siswa, meningkatkan kemandirian siswa. Penelitian yang relevan dengan penelitian ini adalah penelitian yang dilakukan oleh Suparman dan Dwi Nastuti Husen yang berjudul "Peningkatan Kemampuan Berfikir Kreatif Siswa Melalui Penerapan Model PJBL" didapatkan hasil yang sama yaitu Indikator ketrampilan berfikir kreatif yang tinggi adalah keterampilan berpikir lancar (fluency) sedangkan nilai terendah pada indikator keterampilan berpikir asli (originality). Secara keseluruhan perolehan nilai rata-rata kelas ketrampilan berfikir kreatif dan pemahaman konsep IPA masuk dalam kategori baik.

Berdasarkan hasil analisis data penelitian yang telah dilakukan membuktikan bahwa penerapan PJBL berbasis STEM dapat meningkatkan ketrampilan berfikir kreatif siswa kelas VII D SMPN 4 Sumedang diperoleh bahwa rata-rata pencapaian keterampilan berpikir kreatif siswa sebelum dan sesudah pembelajaran dengan STEM project-based learning berbeda secara signifikan, dan pengaruhnya besar. Hal ini didukung oleh hasil penelitian yang relevan, seperti yang dinyatakan oleh Mayasari, dkk (2014) pembelajaran terintegrasi pada bidang STEM memiliki pengaruh positif pada prestasi belajar peserta didik.

Hasil wawancara juga menunjukkan hal yang positif, bahwa secara umum siswa merasa bahwa pembelajaran yang diterapkan bermanfaat bagi mereka. Hal ini disebabkan karena dalam STEM project-based learning siswa diajak untuk melakukan pembelajaran yang bermakna dalam memahami sebuah konsep. Siswa diajak bereksplorasi melalui sebuah kegiatan proyek, sehingga siswa terlibat aktif dalam prosesnya. Hal ini menumbuhkan siswa untuk berpikir kritis, kreatif, analitis.

\section{KESIMPULAN}

Berdasarkan penelitian yang dilakukan dapat disimpulkan bahwa terjadi peningkatan pemahaman konsep Energi pada media PLTMH melalui pendekatan STEM dengan nilai Gain pada siklus 1 sebesar 0,54 kategori sedang menjadi 0,72 pada siklus 2 dengan kategori tinggi. Nilai rata-rata ketrampilan berfikir kreatif siklus I dan siklus 2 yang dinyatakan dengan rata-rata penilaian kreatif proses mengalami peningkatan dengan perolehan pada siklus 1 sebesar 62,4 yang dikategorikan cukup dan pada siklus 2 sebesar 78 yang dikategorikan baik. Sedangkan rata rata penilaian kreatif produk pada siklus 1 sebesar 63,2 dikategorikan cukup dan mengalami peningkatan dengan rata rata penilaian sebesar 80,3 dengan kategori baik. Berdasarkan hasil analisis tersebut membuktikan bahwa pembelajaran berbasis STEM melalui projek PLTMH, dapat meningkatkan pemahaman konsep Energi dan ketrampilan berfikir kreatif pada siswa kelas VII D SMPN 4 Sumedang.

\section{REKOMENDASI}

Tuliskan rek Untuk lebih meningkatkan pemahaman peserta didik tentang factor-faktor yang mempengaruhi besarnya arus listrik yang dihasilkan, perlu penelitian lebih lanjut dengan beberapa variabel yang diubah, baik debit air, maupun jumlah sudu, sudut jarak antar kincir, maupun tegangan dinamo.omendasi berdasarkan hasil penelitian di sini. 


\section{DAFTAR PUSTAKA}

Asmuniv. (2015). Pendekatan Terpadu Pendidikan STEM Upaya Mempersiapkan Sumber Daya Manusia Indonesia Yang Memiliki Pengetahuan Interdisipliner Dalam Menyosong Kebutuhan Bidang Karir Pekerjaan Masyarakat Ekonomi ASEAN (MEA). Diakses dari http://www.vedcmalang.com/pppptkboemlg/index.php/menuutama/listrik-electro/1507asv9.

Hasanah, Lt. (2019). Penerapan Cooperatif Learning Tipe Team Assisted Individualization Untuk Meningkatkan Hasil Belajar Siswa Pada Materi Persamaan Garis Lurus. Jurnal Wahana Pendidikan 5 (2), 60-67.

Mayasari, T., Kadarohman, A., Rusdiana, D. (2014). Pengaruh Pembelajaran Terintegrasi Science, Technology, Engineering, And Mathematics (STEM) Pada Hasil Belajar Peserta Didik: Studi Meta Analisis. Surabaya.

Munandar. (1999). Pengembangan kreativitas Anak Berbakat. Jakarta: Rineka Cipta.

Pradita, Yulistyana. Mulyani, Bakti. Redjeki, Tri. (2015). Penerapan Model Pembelajaran Project Based Learning Untuk Meningkatkan Prestasi Belajar Dan Kreativitas Siswa Pada Materi Pokok Sistem Koloid Kelas XI IPA Semester Genap Madrasah Aliyah Negeri Klaten Tahun Pelajaran 2013/2014. Surakarta: Jurnal Pendidikan Kimia Vol.4 No.1. Hal. 89-96,

Suparman dan Dwi Nastuti Husen. (2015). Peningkatan Kemampuan Berfikir Kreatif Siswa Melalui Penerapan Model PJBL. Ternate: Universitas Khoirun. 